\title{
A recommendation for IVF lab practice in light of the current COVID-19 pandemic
}

\author{
Amir Arav ${ }^{1}$ \\ Received: 22 April 2020 / Accepted: 21 May 2020 / Published online: 28 May 2020 \\ (C) Springer Science+Business Media, LLC, part of Springer Nature 2020
}

A global health threat has been declared by the World Health Organization due to the recent outbreak of COVID-19. Although the exact transmission mechanism is yet unknown, it is known that people positive to the virus are contagious due to small aerosols spreading. According to Adrian [1], a virus in a thin layer of $(1 \mu \mathrm{m})$ of water will vitrify upon cooling into liquid nitrogen (LN). Furthermore, Bielanski [2] has demonstrated that viral contamination of embryos cryopreserved in $\mathrm{LN}$ raises real threat. This data is a cause for concern regarding the current cryo-storage practice in IVF labs. If aerosol drops containing virus touch LN, they will vitrify and contaminate the LN. Four possible scenarios may be possible: (1) vitrified drops can contaminate sperm, oocytes, or embryos which are cryopreserved by open system vitrification, and also, the virus could be transferred to the patient following warming; (2) it can cross-contaminate samples with ACE-2 receptor such as ovarian and testis tissues [3, 4]; (3) it may contaminate the operator upon warming; and (4) it may not cause any contamination if the number of viral load is low or if the virus does not survive.

In order to overcome the above scenarios, several solutions may be applicable: (1) The use of closed system vitrification systems incorporating CBS straws or other systems [5]. (2) The use of sterile LN and vapor storage [6]. (3) Another option is the use of UV sterilization of LN [7] or the use of sterile liquid air for cooling and storage [8]. Finally, if it is true that $15-26 \%$ of SARS-CoV-2 patients present the virus in their semen [9], then washing, separation, and storage (quarantine) in a separate container or in special canister [8] should be done as safety measures.

Until properties of viruses like SARS-CoV-2 are fully investigated with respect to the interaction with $\mathrm{LN}$ and reproductive cells and tissues, cautionary measures as those mentioned above should be taken under serious advisement.

\section{References}

1. Adrian M, Dubochet J, Lepault J. Cryo-electron microscopy of viruses. Nature. 1984;308:32-6.

2. Bielanski A, Bergeron B, Lau B, Devenish J. Viral contamination of embryos cryopreserved in liquid nitrogen. Cryobiology. 2003;46: 146-52.

3. Fernando M, Reis FM, Daniela R, Bouissou DR, Virginia M, Pereira VP, et al. Angiotensin-(1-7), its receptor Mas, and the angiotensinconverting enzyme type 2 are expressed in the human ovary. Fertil Steril. 2011;95(1):176-81.

4. Douglas GC, O’Bryan MK, Hedger MP, Lee DK, Yarski MA, Smith $\mathrm{AI}$, et al. The novel angiotensin-converting enzyme (ACE) homolog, ACE2, is selectively expressed by adult Leydig cells of the testis. Endocrinology. 2004;145(10):4703-11.

5. Schiewe MC, Zozula S, Anderson RE, Fahy GM. Validation of microSecure vitrification ( $\mu \mathrm{S}-\mathrm{VTF})$ for the effective cryopreservation of human embryos and oocytes. Cryobiology. 2015;71:264-72.

6. Cobo A, Romero J, Pérez S, de los Santos M, Meseguer M, Remohí J. Fertility and sterility. 2010;94(5):1903-7.

7. Parmegiani L, Accorsi A, Cognigni G, Bernardi S, Troilo E, Filicori M. Sterilization of liquid nitrogen with ultraviolet irradiation for safe vitrification of human oocytes or embryos. Fertil Steril. 2010;94(4): 1525-8.

8. Arav A, Natan Y, Levi-Setti P, Menduni F, Patrizio P. New methods for cooling and storing oocytes and embryos in a clean environment of $-196^{\circ} \mathrm{C}$. Reprod BioMed Online. 2016;33(1):71-8.

9. Li D, Jin M, Bao P, Zhao W, Zhang S. Clinical characteristics and results of semen tests among men with coronavirus disease 2019. JAMA Netw Open. 2020;3(5).

Publisher's note Springer Nature remains neutral with regard to jurisdictional claims in published maps and institutional affiliations.

Amir Arav

Fertilesafe@gmail.com

1 FertileSafe LTD Israel, Tel Aviv, Israel 